\title{
Gallstone obstruction in anastomotic stricture: A very rare case
}

\author{
Anastomoz darlığında safra taşı ileusu: Nadir bir vaka \\ Burak Veli Ülger ${ }^{1}$, Ömer Uslukaya ${ }^{1}$, Abdullah Oğuz ${ }^{1}$, Ercan Gündüz ${ }^{2}$, Memik Teke ${ }^{3}$, Bilsel Baç ${ }^{1}$
}

\begin{abstract}
Gallstone ileus is a rare but serious complication of cholelithiasis. It is a rare cause of small bowel obstruction but it accounts up to $25 \%$ of non-strangulated small bowel obstructions in elderly. Obstruction usually occurs in the terminal ileum. Although the most frequent mechanism of gallstone ileus is migration of the gallstone through a gallbladder-duodenal fistula, there have been cases of bowel obstruction caused by gallstones without any findings of bilio-enteric fistula during the operation. The diagnosis is usually delayed due to nonspecific clinical signs and symptoms. Abdominal computerized tomography (CT) scan is the optimal way to diagnose the gallstone ileus. It can identify the site and nature of the obstruction. The optimal surgical approach is a matter of debate. Enterolithotomy is the most performed operation. One stage operation should be performed in selected low risk patients. In this study, we report a 55 years old male patient who underwent surgical intervention due to gallstone ileus. During the operation, we observed that two individual gallstones lead to obstruction in anastomotic stricture which was due to the patient's prior small bowel resection. Also, no fistula was found during the operation between the gall bladder and the gastrointestinal tract of patient. The gallstones were removed by enterolithotomy. Because there was no gallstone in the gallbladder, we did not perform cholecystectomy. J Clin Exp Invest 2015; 6 (1): $72-74$
\end{abstract}

Key words: Gallstone ileus, anastomotic stricture, bilioenteric fistula

\section{INTRODUCTION}

Gallstone ileus is a mechanical obstruction caused by the impaction of gallstone within the lumen of the gastrointestinal tract (GIT). Usually migration of the gallstone occurs through a fistula between gallbladder and GIT, but it can be seen without a fistula and

\section{ÖZET}

Safra taşı ileusu, kolelitiazis'in nadir ama ciddi bir komplikasyonudur. İnce barsak tıkanıklıklarının nadir bir nedeni olmasına rağmen, yaşılarda strangulasyon'a bağlı olmayan ince barsak tıkanıklıklarının \%25'inin sebebidir. Tıkanıklık, genellikle terminal ileum'da gerçekleşir. Safra taşı ileusu'nun en sık oluş mekanizması safra kesesi duodenum arasındaki bir fistülden safra taşının migrasyonu olsa da, ameliyat sırasında bilio-enterik fistül saptanamayan vakalar da rapor edilmiştir. Hastalığın tanısı, nonspesifik belirti ve bulgular nedeniyle genellikle gecikir. Safra taşı ileusu tanısını koymada abdominal bilgisayarlı tomografi ideal olan bir yöntemdir. Tıkanıklığın yerini ve özelliğini gösterebilir. En uygun cerrahi yöntem ise tartışmalıdır. Enterolitotomi en sık uygulanan yöntemdir. Tek aşamalı ameliyat ise, sadece seçilmiş düşük riskli hastalarda yapılmalıdır. Bu çalışmamızda, safra taşı ileusu nedeniyle ameliyat ettiğimiz 55 yaşındaki erkek bir hastayı sunuyoruz. Ameliyatta, 2 adet safra taşının hastanın daha önce geçirdiği ince barsak rezeksiyonundan sonra oluşan anastomoz darlığında tıkanıklığa neden olduğu saptandı. Ayrıca, hastanın safra kesesi ile gastrointestinal kanalı arasında fistülün olmadığı da saptandı. Enterolitotomi ile safra taşları çıkartıldı. Safra kesesinde taş saptanmadığı için, kolesistektomi yapılmadı.

Anahtar kelimeler: Safra taşı ileusu, anastomoz darlığı, bilio-enterik fistül

\footnotetext{
${ }^{1}$ Dicle Üniversitesi Tıp Fakültesi Genel Cerrahi Anabilim Dalı Diyarbakır, Türkiye

${ }^{2}$ Dicle Üniversitesi Tıp Fakültesi Acil Tıp Anabilim Dalı Diyarbakır, Türkiye

${ }^{3}$ Dicle Üniversitesi Tıp Fakültesi Radyoloji Anabilim Dalı Diyarbakır, Türkiye
}

Correspondence: Burak Veli Ülger,

Dicle Üniversitesi Tıp Fakültesi Genel Cerrahi Ana Bilim Dalı, Diyarbakır, Türkiye Email: bvulger@gmail.com

Received: 12.01.2015, Accepted: 01.02.2015

Copyright @ JCEI / Journal of Clinical and Experimental Investigations 2015, All rights reserved 


\section{CASE REPORT}

We report a 55 years old male patient who presented with intermittent abdominal pain, nausea, vomiting, abdominal distension and obstipation. He had been having similar symptoms for the previous 3 months. He had a history of prior segmental small bowel resection due to strangulation ten years ago. The physical examination revealed a distended abdomen, with no palpable masses and no hernias. Plain abdominal $x$ ray revealed distended small bowel segments and 2 radio-opaque stones in the abdomen (Figure 1). Abdominal CT scan revealed intestinal distension and two individual radio opaque gallstones in the lumen of the ileum, so the diagnosis of gallstone ileus was established (Figure 2).

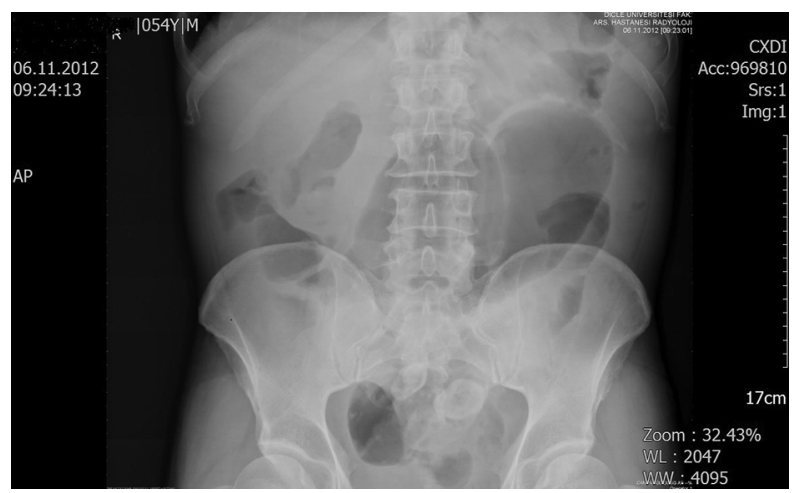

Figure 1. Plain abdominal $x$ ray revealed distended small bowel segments and two radio-opaque stones in the abdomen

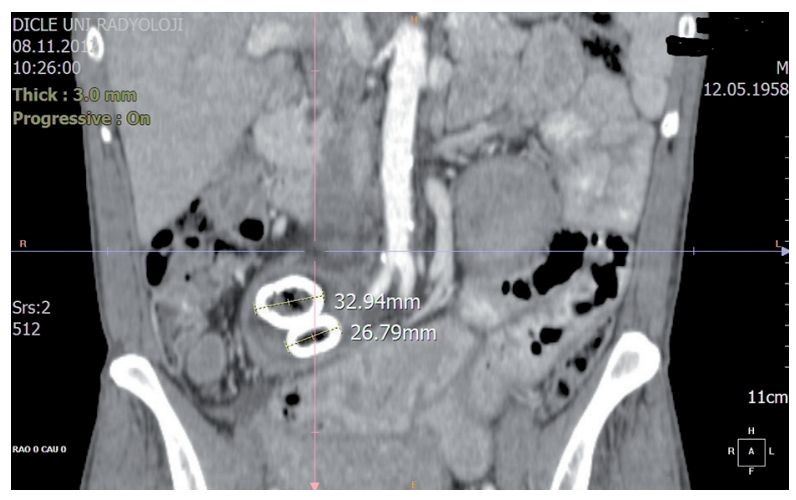

Figure 2. Abdominal CT scan revealed two gallstones in the lumen of the ileum

Laparotomy revealed distended loops of small bowel and a clear transition zone from dilated to collapsed bowel just proximal to the previous ileo-ileal anastomosis. Two individual stones were palpated at this site. The stones were propelled backwards through the jejunum and then the patient underwent enterolithotomy (Figure 3). No other gallstones were detected by manual examination of the intestine and gallbladder. No sign of bilio-enteric fistula was observed during the operation. Because there was no gallstone in the gallbladder, we did not perform cholecystectomy. The patient was discharged uneventfully on sixth day after surgery.

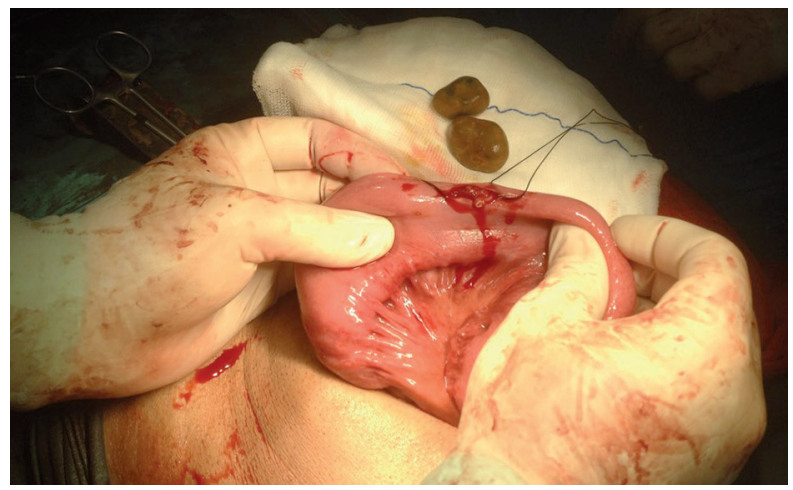

Figure 3. The patient underwent enterolithotomy

\section{DISCUSSION}

Gallstone ileus was first described by Bartholin in 1654 [1]. It accounts for $1-4 \%$ of all mechanical bowel obstructions, and $25 \%$ of small bowel obstructions in patients older than 65 years [2]. The obstructing stone originates from the gallbladder. Recurrent calculous cholecystitis usually results in extensive inflammation and adhesion between the gallbladder and the GIT. This facilitates the erosion by the gallstone through the wall of the gallbladder into the gut to form cholecystoenteric fistula and eventual passage into the gut [3]

The fistula can occur anywhere in the GIT including the stomach, the colon, and the small bowel [4]. The size of the stone and the luminal diameter are the two main factors determining whether obstructions will occur. Generally, obstruction due to gallstones occurs in the terminal ileum and the ileocaecal valve [2]. Although the most frequent mechanism of gallstone ileus is migration of the gallstone through a gallbladder-duodenal fistula (68\%-96.5\%) [5], there have been cases of bowel obstruction caused by gallstones without any findings of bilioenteric fistula during the operation [6]. Bowel strictures due to inflammatory diseases were thought to be responsible for this situation.

Gallstone ileus is associated with high morbidity and mortality, due to delay in diagnosis and the predominance of elderly patients. Diagnosis is usually delayed due to nonspecific clinical symptoms and signs of the disease [2]. Plain abdominal ra- 
diographs, abdominal ultrasound (US) and CT have been used for diagnosis. Classical Rigler's triad [4] of pneumobilia, presence of ectopic gallstone, and mechanical bowel obstruction has been shown to be present in less than half of the patients with gallstone ileus. CT scan allows detection of the specific location and size of the ectopic stone, the site of bowel obstruction, and direct visualization of the biliary-enteric fistula [7].

Optimal surgical treatment for this gallstone ileus is a matter of debate. Surgical treatment options include enterolithotomy with or without interval cholecystectomy or one-stage enterolithotomy, cholecystectomy, and repair of the fistula. Enterolithotomy is mostly performed procedure, with lower morbidity and mortality [4]. One-stage surgery has prolonged operation and additional surgical trauma, but it is preferred in selected low risk patients in order to prevent recurrence of gallstone ileus and recurrent ascending cholangitis [2].

In conclusion, gallstones may enter the gastrointestinal tract even if the fistula does not persist, and lead to gallstone ileus by impacting proximal to an anastomotic stricture. Surgical approach should depend on the underlying pathology and the condi- tion of the patient. After enterolithotomy; gallbladder, the entire small bowel and colon should be digitally examined for further stones.

\section{REFERENCES}

1. Martin F. Intestinal obstruction due to gallstones. Ann Surg 1912;55:725.

2. Ayantunde AA, Agrawal A. Gallstone lleus: Diagnosis and Management. World J Surg 2007;31:1292-1297.

3. Lassandro RS, Ragozzino A, et al. Role of helical CT in diagnosis of gallstone ileus and related conditions. AJR 2005;185:1159-1165.

4. Ravikumar R, Williams JG. The operative management of gallstone ileus. Ann R Coll Surg Engl 2010;92:279_ 281.

5. Nakao A, Okamoto $Y$, Sunami $M$, et al. The oldest patient with gallstone ileus: report of a case and review of 176 cases in Japan. Kurumo Medical Journal 2008;55:29-33.

6. Goyal A, Srivastava A. Gallstone ileus following endoscopic retrograde cholangiopancreatography and sphincterotomy: a case report. Journal of Medical Case Reports 2008;2:342.

7. Yu CY, Lin CC, Shyu RY, et al. Value of CT in the diagnosis and management of gallstone ileus. World $\mathrm{J}$ Gastroenterol 2005;11:2142-2147. 